\title{
Parameter Optimization of Injection Molding of Polypropylene by using Taguchi Methodology
}

\author{
M. V. Kavade ${ }^{1}$, S. D. Kadam ${ }^{2}$ \\ ${ }^{1,2}$ (Mechanical Engineering Department, Rajarambapu Institute of Technology, Sakharale, Islampur, Sangli. \\ Maharashtra State (INDIA))
}

\begin{abstract}
Injection molding is an important polymer processing operation in the plastic industry. In this process, polymer is injected into a mold cavity, and solidifies to the shape of the mold. Optimizing the parameters of the injection molding process is critical to enhance productivity. For process optimization, parameters must operate at optimum levels for acceptable performance. Taguchi method is one of the methods of optimization, in which orthogonal array is generated based on experimental design. Optimization of injection molding process parameters will be carried out using polypropylene $(P P)$ as the molding material
\end{abstract}

Keywords - Coolant Flow rate, Injection Molding Optimization, Taguchi methodology,

\section{Introduction}

Injection Molding is a cyclic process for producing identical articles from a mold, and is the most widely used for polymer processing. The main advantage of this process is the capacity of repetitively fabricating parts having complex geometries at high production rates. Complexity is virtually unlimited and sizes may range from very small to very large. Most polymers may be injection molded, including thermo plastics, fiber reinforced thermo plastics, thermosetting plastics, and elastomers. Critical to the adoption of this high volume, low cost process technology is the ability to consistently produce quality parts.

Table No. 1 Parameters Considered by Various Authors for Process Optimization

\begin{tabular}{|c|c|c|c|c|c|c|c|c|c|c|c|c|c|c|}
\hline \multirow{2}{*}{$\begin{array}{l}\text { REFERANCE } \\
\text { NUMBER }\end{array}$} & \multicolumn{11}{|c|}{ PARAMETERS CONSIDERED } & \multirow{2}{*}{$\begin{array}{l}\text { OPTIMIZATION } \\
\text { METHOD }\end{array}$} & \multirow{2}{*}{$\begin{array}{l}\text { RESPONSE } \\
\text { STUDIED }\end{array}$} & \multirow{2}{*}{$\begin{array}{l}\text { NOTATIONS } \\
\text { USED }\end{array}$} \\
\hline & a & $\mathrm{b}$ & $\mathrm{c}$ & $\mathrm{d}$ & e & f & $\mathrm{g}$ & $\mathrm{h}$ & $\mathrm{i}$ & $\mathrm{j}$ & $\mathrm{k}$ & & & \\
\hline 1 & & & 冰 & $*$ & 冰 & $*$ & * & * & * & & $*$ & $\begin{array}{l}\text { PCA\& REGRESSION } \\
\text { ANALYSIS }\end{array}$ & QUALITY & $\begin{array}{l}\text { a-FILLING } \\
\text { TIME }\end{array}$ \\
\hline 2 & 冰 & & & & * & $*$ & * & & & & $*$ & $\begin{array}{l}\text { DOE \& KRIGING } \\
\text { ALGORITHM }\end{array}$ & WARPAGE & $\begin{array}{l}\mathrm{b}-\text { INJECTION } \\
\text { TEMPERATURE }\end{array}$ \\
\hline 3 & 氺 & & & & $*$ & * & * & & & & 米 & $\begin{array}{l}\text { ANN \& GENETIC } \\
\text { ALGORITHM }\end{array}$ & $\begin{array}{l}\text { PARAMETER } \\
\text { LEVELS }\end{array}$ & $\begin{array}{l}\mathrm{c}-\text { INJECTION } \\
\text { SPEED }\end{array}$ \\
\hline 4 & & & 将 & $*$ & * & $*$ & * & $*$ & & $*$ & $*$ & $\begin{array}{l}\text { TAGUCHI } \\
\text { METHOD }\end{array}$ & $\begin{array}{l}\text { TENSILE } \\
\text { STRENGTH }\end{array}$ & $\begin{array}{l}d-\text { INECTION } \\
\text { PRESSURE }\end{array}$ \\
\hline 5 & 将 & & & & $*$ & $*$ & * & * & & & $*$ & $\begin{array}{l}\text { GENETIC } \\
\text { ALGORITHM }\end{array}$ & $\begin{array}{l}\text { RUNNER } \\
\text { DESIGN }\end{array}$ & $\begin{array}{l}\text { e-BARREL } \\
\text { TEMPERATURE }\end{array}$ \\
\hline 6 & 冰 & & & & $*$ & * & * & & & & & $\begin{array}{l}\text { TAGUCHI } \\
\text { METHOD }\end{array}$ & WARPAGE & $\begin{array}{l}\text { f-HOLDING } \\
\text { PRESSURE }\end{array}$ \\
\hline 7 & 冰 & 将 & & & & & & & & & $*$ & 3D-SIMULATION & $\begin{array}{l}\text { FLOW } \\
\text { ANALYSIS }\end{array}$ & $\begin{array}{l}\text { g- HOLDING } \\
\text { TIME }\end{array}$ \\
\hline 8 & 将 & & 将 & $*$ & & & & & & & & 3D-SIMULATION & GATE DESIGN & $\begin{array}{l}\mathrm{h}-\text { COOLING } \\
\text { TIME }\end{array}$ \\
\hline 9 & & & 将 & & & $*$ & $*$ & & & $*$ & & FEM MODELLING & $\begin{array}{l}\text { DIMENSIONAL } \\
\text { STABILITY }\end{array}$ & $\begin{array}{l}\text { i-SCREW } \\
\text { STROKE }\end{array}$ \\
\hline & & \multirow{2}{*}{ DIC } & & & & & & & & & & & & $\begin{array}{l}\mathrm{j}-\text { NOZZLE } \\
\text { TEMPERATURE }\end{array}$ \\
\hline & & & & & & RAI & IET & ER & & & DE & RED AT VARIED I & & $\begin{array}{l}\text { k-MOLD } \\
\text { TEMPERATURE }\end{array}$ \\
\hline
\end{tabular}

The above Table highlights the importance of selection of parameters and the significance of their optimum levels to achieve a robust process or parameter design [1-9]. The parameters like screw stroke, injection temperature have been found out less important and nozzle temperature has been substituted for barrel temperature. Filling time is dependent on injection speed and injection pressure and hence, need not be considered. Most of the researchers have considered mold temperature as a very important parameter [1-5, 7]. A module called Mold Temperature Controller (MTC), used to control mold temperature; is very expensive and generally not incorporated in the basic control system. This constrains the effective control of the output of injection molding.In absence of mold temperature controller (MTC), optimization of process parameters can be achieved considering the coolant flow rate along with other process parameters [10]. In cooling system design, design variables typically include the size, location and layout of cooling channels, and the thermal properties, 
temperature and flow rate of the coolant. The mold temperature modulation can be achieved and in turn the consideration of coolant flow rate as an input parameter for robust process optimization of injection molding. Basic Injection Molding process will be studied, and monitored. Optimization of injection molding process parameters will be carried out using polypropylene (PP) as the molding material, due to its universality as the most common injection molding material.

The design of experiment (D.O.E.) chosen for the Injection Molding of Polypropylene is Taguchi $\mathrm{L}_{18}$ $\left(2^{1} \times 3^{7}\right)$ orthogonal array, by carrying out a total number of 18 experiments along with a verification experiment. The parameters to be considered for the robust parameter design of polypropylene material are:

a) Barrel Temperature b) Injection Pressure c) Injection Speed d) Holding Pressure
e) Holding Time
f) Cooling Time
g) Coolant Flow Rate

Weight will be the output response to study the variation in output due to changes in the levels of process parameters. The work material used is (Polypropylene with Impact Copolymer variant) and is recommended for use in Injection Molding processes where high flow and medium impact strength are required. It is an ideal material for rigid packaging, automotive components, housewares and parts of appliances.

Input Factors with Units \& Notation:-
1) Barrel Temperature, ${ }^{\circ} \mathrm{C} \quad-[\mathrm{A}]$
2) Injection pressure, $\mathrm{MPa} \quad-[\mathrm{B}]$
3) Injection speed, $\% \quad-[\mathrm{C}]$
4) Coolant flow rate, $1 / \mathrm{m} \quad$ - [D]
5) Holding pressure, $\mathrm{MPa} \quad-[\mathrm{E}]$
6) Holding time, second $\quad-[\mathrm{F}]$
7) Cooling time, second - $[\mathrm{G}]$

Response Measured with Unit \& Notation:-

1) Weight, gram - [W]

Any surface defect during the trials will be noted as an attribute data.

In Taguchi $\mathrm{L}_{18}\left(2^{1} \times 3^{7}\right)$ orthogonal array 18 rows represent the 18 experiments to be conducted with 7 columns at, 3 levels of the corresponding factors. ANOVA will be used for statistical evaluation of experimental observations. F- Ratio will be used to determine the confidence intervals.

Table No. 2 : Level Values of Input Factors

\begin{tabular}{|c|c|c|c|c|c|}
\hline \multirow[t]{2}{*}{ Sr.No } & \multirow{2}{*}{\multicolumn{2}{|c|}{ Factors }} & \multicolumn{3}{|c|}{ Levels } \\
\hline & & & 1 & 2 & 3 \\
\hline 1 & Barrel Temperature & [A] & 215 & 225 & 235 \\
\hline 2 & Injection Pressure & [B] & 30 & 40 & 45 \\
\hline 3 & Injection Speed & {$[\mathrm{C}]$} & 40 & 45 & 50 \\
\hline 4 & Coolant Flow Rate & [D] & 4 & 7 & 11 \\
\hline 5 & Holding Pressure & {$[\mathrm{E}]$} & 35 & 40 & 45 \\
\hline 6 & Holding Time & {$[\mathrm{F}]$} & 1.5 & 1.75 & 2.0 \\
\hline 7 & Cooling Time & [G] & 5.5 & 5.75 & 6.0 \\
\hline
\end{tabular}

\section{Design of Experiment}

Fig. No. 1 shows schematic diagram of the experimental set-up. The flow control valves (B1, B2), were used to control the coolant flow to the mold and the flow was measured by the flow meter, (V). The control parameters were varied according to the orthogonal array design and the weight of the molded parts were measured with the help of a Weighing Machine. The cycle time was also noted. The surfaces of molded pieces were studied for any defects related to molding and none was observed. 


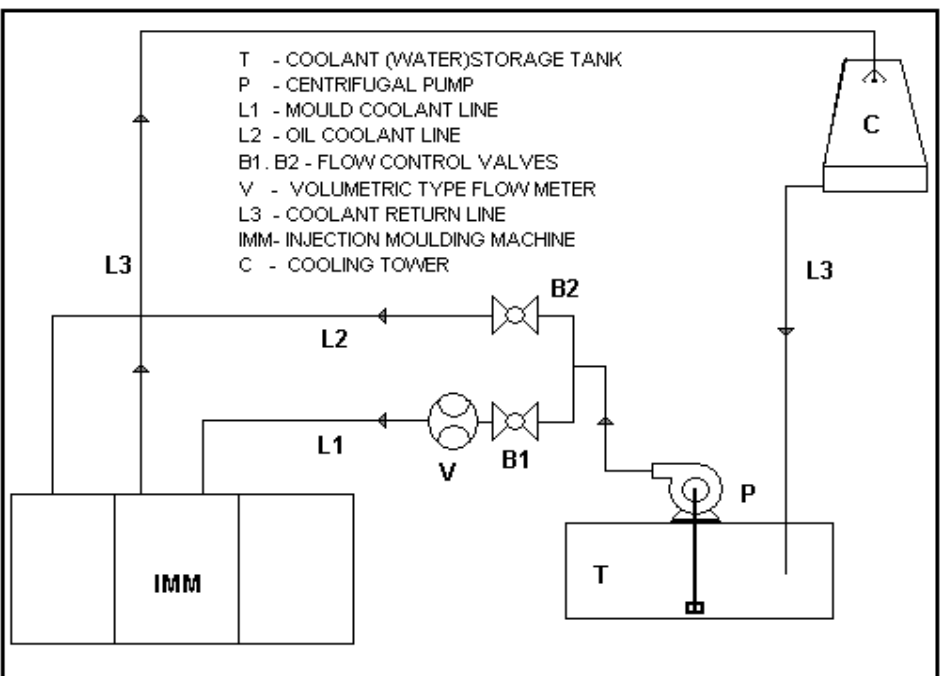

Figure. No. 1 Injection Molding Experimental Set Up

Table No: 3 Taguchi $\mathrm{L}_{18}$ Orthogonal Array

\begin{tabular}{|c|c|c|c|c|c|c|c|}
\hline Expt No. & $\mathrm{A}$ & $\mathrm{B}$ & $\mathrm{C}$ & $\mathrm{D}$ & $\mathrm{E}$ & $\mathrm{F}$ & $\mathrm{G}$ \\
\hline 1 & 215 & 30 & 40 & 4 & 35 & 1.50 & 5.50 \\
\hline 2 & 225 & 40 & 45 & 7 & 40 & 1.75 & 5.50 \\
\hline 3 & 235 & 45 & 50 & 11 & 45 & 2.00 & 5.50 \\
\hline 4 & 235 & 30 & 45 & 4 & 40 & 2.00 & 5.50 \\
\hline 5 & 215 & 40 & 50 & 7 & 45 & 1.50 & 5.50 \\
\hline 6 & 225 & 45 & 40 & 11 & 35 & 1.75 & 5.50 \\
\hline 7 & 225 & 30 & 50 & 7 & 35 & 2.00 & 5.75 \\
\hline 8 & 235 & 40 & 40 & 11 & 40 & 1.50 & 5.75 \\
\hline 9 & 215 & 45 & 45 & 4 & 45 & 1.75 & 5.75 \\
\hline 10 & 225 & 30 & 45 & 11 & 45 & 1.50 & 5.75 \\
\hline 11 & 235 & 40 & 50 & 4 & 35 & 1.75 & 5.75 \\
\hline 12 & 215 & 45 & 40 & 7 & 40 & 2.00 & 5.75 \\
\hline 13 & 235 & 30 & 40 & 7 & 45 & 1.75 & 6.0 \\
\hline 14 & 215 & 40 & 45 & 11 & 35 & 2.00 & 6.0 \\
\hline 15 & 225 & 45 & 50 & 4 & 40 & 1.50 & 6.0 \\
\hline 16 & 215 & 30 & 50 & 11 & 40 & 1.75 & 6.0 \\
\hline 17 & 225 & 40 & 40 & 4 & 45 & 2.00 & 6.0 \\
\hline 18 & 235 & 45 & 45 & 7 & 35 & 1.50 & 6.0 \\
\hline
\end{tabular}

Notations used in the calculations are as given:-

$\mathrm{S} / \mathrm{N}$---- Signal to Noise ratio for given response Weight and its unit is $\mathrm{dB}$

$\mathrm{k}_{\mathrm{q}} \quad$---- level for the factor denoted by subscript q. $\mathrm{q} \square\{\mathrm{A}, \mathrm{B}, \mathrm{C}, \mathrm{D}, \mathrm{E}, \mathrm{F}, \mathrm{G}\}$

$\mathrm{v}_{\mathrm{q}} \quad$---- degree of freedom for the factor denoted by subscript q. $\mathrm{q} \square\{$ A,B,C,D,E,F,G\}

$\mathrm{v}_{\mathrm{m}} \quad$---- degree of freedom for associated with the mean \{always equal to 1 \}

$\mathrm{v}_{\mathrm{e}} \quad$---- degree of freedom associated with the error

$\mathrm{N} \quad----$ total number of observations

$\mathrm{T} \quad$---- sum of all observations

$\mathrm{T}_{\mathrm{m}} \quad----$ average of all observations

$\mathrm{V}_{\mathrm{q}} \quad$---- variance for the factor denoted by subscript q. $\mathrm{q} \square\{\mathrm{A}, \mathrm{B}, \mathrm{C}, \mathrm{D}, \mathrm{E}, \mathrm{F}, \mathrm{G}\}$

$\mathrm{S}_{\mathrm{e}} \quad----$ Pooled Error Standard Deviation

$\mathrm{SS}_{\mathrm{m}} \quad---$ Sums of Squares due to Mean

$\mathrm{SS}_{\mathrm{T}} \quad---$ Total Sums of Squares of Weights,

$\mathrm{SS}_{\mathrm{q}} \quad$---- Sums of Squares for Factors denoted by subscript q. q $\square\{$ A,B,C,D,E,F,G\}

$\mathrm{SS}_{\mathrm{e}} \quad$---- Sums of Squares of Error 
SS ---- Sums of Squares

$\% \mathrm{P} \quad----$ percent contribution

F ---- F- Ratio

CI ---- Confidence Interval

$\alpha \quad----$ risk

For Weight, the calculation of S/N ratio follows "Smaller the Better" model.

For smaller the better, $\mathrm{S} / \mathrm{N}$ is given by;

$$
\begin{aligned}
\mathbf{S} / \mathbf{N} & =-10 \log (\operatorname{MSD}) \quad \text { where } \quad \mathrm{MSD}=\frac{1}{n} \sum_{i=1}^{n} \mathrm{w}_{i}^{2} \\
& =-10 \log \left(\frac{1}{n} \sum_{i=1}^{n} \mathrm{w}_{i}^{2}\right)
\end{aligned}
$$

where MSD is the mean square deviation,

$\mathrm{w}$ ( the observation) Weight, and $\mathrm{i}$ is the iterant

$\mathrm{n}$ is the number of tests in a trial.

Total Sums of Squares of Weights,

$$
\mathbf{S S}_{\mathrm{T}}=\sum_{i=1}^{\mathrm{N}} \mathrm{w}_{i}^{2}
$$

For any Factor the Sums of Squares is

$$
\mathbf{S S}_{\mathrm{q}}=\left[\sum_{i=1}^{\mathbf{k}_{\mathbf{q}}}\left(\frac{\mathbf{q}_{i}^{2}}{\mathbf{n}_{\mathbf{q}_{i}}}\right)\right]-\frac{\mathbf{T}^{2}}{\mathrm{~N}}
$$

\section{Experimental Result}

The part showed excellent surface texture and specifically 'gloss' in terms of commercial terms of product value. The experimental observations and calculated S/N ratios are shown in TABLE No. 4.

Table. No. 4- S/N Ratios

\begin{tabular}{|c|c|c|c|c|c|c|c|c|c|c|c|}
\hline $\begin{array}{c}\text { Expt } \\
\text { No. }\end{array}$ & $\mathrm{A}$ & $\mathrm{B}$ & $\mathrm{C}$ & $\mathrm{D}$ & $\mathrm{E}$ & $\mathrm{F}$ & $\mathrm{G}$ & $\mathrm{CT}$ & $\mathrm{W}$ & $\mathrm{W}^{2}=(\mathrm{W} * \mathrm{~W})$ & $\mathrm{S} / \mathrm{N}(\mathrm{dB})$ \\
\hline 1 & 215 & 30 & 40 & 4 & 35 & 1.50 & 5.50 & 29.6 & 96.378 & 9288.71888 & -39.6796 \\
\hline 2 & 225 & 40 & 45 & 7 & 40 & 1.75 & 5.50 & 29.6 & 96.742 & 9359.01456 & -39.7123 \\
\hline 3 & 235 & 45 & 50 & 11 & 45 & 2.00 & 5.50 & 30.1 & 96.339 & 9281.20292 & -39.6760 \\
\hline 4 & 235 & 30 & 45 & 4 & 40 & 2.00 & 5.50 & 30.2 & 96.697 & 9350.23245 & -39.7082 \\
\hline 5 & 215 & 40 & 50 & 7 & 45 & 1.50 & 5.50 & 30 & 96.534 & 9318.81316 & -39.6936 \\
\hline 6 & 225 & 45 & 40 & 11 & 35 & 1.75 & 5.50 & 30.1 & 96.164 & 9247.51490 & -39.6603 \\
\hline 7 & 225 & 30 & 50 & 7 & 35 & 2.00 & 5.75 & 29.8 & 96.626 & 9336.58388 & -39.7019 \\
\hline 8 & 235 & 40 & 40 & 11 & 40 & 1.50 & 5.75 & 30.1 & 96.585 & 9328.66223 & -39.6982 \\
\hline 9 & 215 & 45 & 45 & 4 & 45 & 1.75 & 5.75 & 28.9 & 96.048 & 9225.21830 & -39.6498 \\
\hline 10 & 225 & 30 & 45 & 11 & 45 & 1.50 & 5.75 & 29.4 & 96.425 & 9297.78063 & -39.6838 \\
\hline 11 & 235 & 40 & 50 & 4 & 35 & 1.75 & 5.75 & 29.2 & 96.806 & 9371.40164 & -39.7180 \\
\hline 12 & 215 & 45 & 40 & 7 & 40 & 2.00 & 5.75 & 29.3 & 96.240 & 9262.13760 & -39.6671 \\
\hline 13 & 235 & 30 & 40 & 7 & 45 & 1.75 & 6.0 & 29.8 & 96.826 & 9375.27428 & -39.7198 \\
\hline 14 & 215 & 40 & 45 & 11 & 35 & 2.00 & 6.0 & 29.4 & 96.480 & 9308.39040 & -39.6887 \\
\hline 15 & 225 & 45 & 50 & 4 & 40 & 1.50 & 6.0 & 28.7 & 96.260 & 9265.98760 & -39.6689 \\
\hline 16 & 215 & 30 & 50 & 11 & 40 & 1.75 & 6.0 & 28.3 & 96.642 & 9339.67616 & -39.7033 \\
\hline 17 & 225 & 40 & 40 & 4 & 45 & 2.00 & 6.0 & 28.4 & 96.184 & 9251.36186 & -39.6621 \\
\hline 18 & 235 & 45 & 45 & 7 & 35 & 1.50 & 6.0 & 28.4 & 96.840 & 9377.98560 & -39.7211 \\
\hline$\sum$ & & & & & & & & & 1736.8156 & 167585.957 & \\
\hline MEAN & & & & & & & & & 96.48976 & & \\
\hline
\end{tabular}


Table. No. 5- Degrees of Freedom

\begin{tabular}{|c|c|c|c|}
\hline Sr. No. & FACTOR & LEVELS- $\mathrm{k}_{\mathrm{q}}$ & DOF $-\mathrm{v}_{\mathrm{q}}$ \\
\hline 1 & $\mathrm{~A}$ & 3 & 2 \\
\hline 2 & $\mathrm{~B}$ & 3 & 2 \\
\hline 3 & $\mathrm{C}$ & 3 & 2 \\
\hline 4 & $\mathrm{D}$ & 3 & 2 \\
\hline 5 & $\mathrm{E}$ & 3 & 2 \\
\hline 6 & $\mathrm{~F}$ & 3 & 2 \\
\hline 7 & $\mathrm{G}$ & 3 & 2 \\
\hline 8 & Error & - & 3 \\
\hline 9 & Mean & - & 1 \\
\hline \multicolumn{2}{|r}{} & TOTAL - $\mathrm{v}_{\mathrm{T}}$ & 18 \\
\hline
\end{tabular}

Table. No. 6- ANOVA - Unpooled

\begin{tabular}{|c|r|c|c|c|c|c|}
\hline SOURCE & SS & $\mathrm{v}$ & $\begin{array}{c}\text { VARIANCE } \\
\mathrm{V}\end{array}$ & F-RATIO & $\% \mathrm{P}$ & $\begin{array}{c}\text { CONFIDENCE } \\
\text { INTERVAL }\end{array}$ \\
\hline $\mathrm{A}$ & 0.333488 & 2 & 0.1667438 & 50.79233 & 31.93268 & $99 \%$ \\
\hline $\mathrm{B}$ & 0.2800781 & 2 & 0.140039 & 42.65772 & 26.81853 & $99 \%$ \\
\hline $\mathrm{D}$ & 0.1947309 & 2 & 0.0973654 & 29.65879 & 18.64621 & $95 \%$ \\
\hline $\mathrm{E}$ & 0.0862102 & 2 & 0.0431051 & 13.13037 & 8.254946 & $95 \%$ \\
\hline $\mathrm{C}$ & 0.07888 & 2 & 0.0394402 & 12.01399 & 7.55309 & $95 \%$ \\
\hline $\mathrm{F}$ & 0.03831 & 2 & 0.0191531 & 5.834277 & 3.667958 & $90 \%$ \\
\hline $\mathrm{G}$ & 0.0228038 & 2 & 0.0114019 & 3.47316 & 2.183545 & - \\
\hline Error & 0.009849 & 3 & 0.0032829 & - & 0.943 & \\
\hline $\mathrm{T}$ & 1.0445 & 17 & & & $100 \%$ & \\
\hline
\end{tabular}

\subsection{Pooling of Error}

The combining of column effects to get better estimate error variance is referred to as pooling. The pooling up strategy entails F-test the smallest column effect against the next larger one to see if significance exists. If no significant F-ratio exists, then these two effects are pooled together to test the next larger column effect until some significant $\mathrm{F}$ ratio exists.

Pooling-up will tend to maximize the number of columns judged to be significant, and it will be used by us to lead us to the verification experiment.

Table. No. 7- ANOVA - Unpooled

\begin{tabular}{|c|r|c|c|c|c|c|}
\hline SOURCE & \multicolumn{1}{|c|}{$\mathrm{SS}$} & $\mathrm{v}_{\mathrm{q}}$ & VARIANCE V & F-RATIO & $\% \mathrm{P}$ & $\begin{array}{c}\text { CONFIDENCE } \\
\text { INTERVAL }\end{array}$ \\
\hline $\mathrm{A}$ & 0.333488 & 2 & 0.1667438 & 50.79233 & 31.93268 & $99 \%$ \\
\hline $\mathrm{B}$ & 0.2800781 & 2 & 0.140039 & 42.65772 & 26.81853 & $99 \%$ \\
\hline $\mathrm{D}$ & 0.1947309 & 2 & 0.0973654 & 29.65879 & 18.64621 & $95 \%$ \\
\hline $\mathrm{E}$ & 0.0862102 & 2 & 0.0431051 & 13.13037 & 8.254946 & $95 \%$ \\
\hline $\mathrm{C}$ & 0.07888 & 2 & 0.0394402 & 12.01399 & 7.55309 & $95 \%$ \\
\hline $\mathrm{F}$ & 0.03831 & 2 & 0.0191531 & 5.834277 & 3.667958 & $90 \%$ \\
\hline $\mathrm{E}_{\mathrm{p}}$ & 0.032652 & 5 & 0.00653 & - & 3.1266 & \\
\hline & & & & & & \\
\hline $\mathrm{T}$ & 1.0445 & 17 & & & 100.00 & \\
\hline
\end{tabular}

The percent contribution and F-ratio of cooling time (D) were insignificant and hence they were pooled with the error estimates along with the degrees of freedom, sums of squares, variance to regenerate the table as result of pooling up strategy employed. 


\subsection{Delta}

Delta $=($ Maximum S/N Ratio - Minimum S/N Ratio $)$

Delta of Barrel Temperature $(\mathrm{A})=(-39.68035+39.70691)=0.026556$

The Delta values and corresponding Ranks are tabulated in the TABLE No. 8.

Table. No. 8 Rank of Factors

\begin{tabular}{|c|c|c|c|c|c|c|c|}
\hline LEVEL & $\begin{array}{c}\text { BARREL } \\
\text { TEMP [A] }\end{array}$ & $\begin{array}{c}\text { INJECTION } \\
\text { PRESSURE } \\
{[\mathrm{B}]}\end{array}$ & $\begin{array}{c}\text { INJECTION } \\
\text { SPEED } \\
{[\mathrm{C}]}\end{array}$ & $\begin{array}{c}\text { COOLANT } \\
\text { FLOW } \\
\text { RATE } \\
{[\mathrm{D}]}\end{array}$ & $\begin{array}{c}\text { HOLDING } \\
\text { PRESSURE } \\
{[\mathrm{E}]}\end{array}$ & $\begin{array}{c}\text { HOLDING } \\
\text { TIME } \\
{[\mathrm{F}]}\end{array}$ & $\begin{array}{c}\text { COOLING } \\
\text { TIME } \\
{[\mathrm{G}]}\end{array}$ \\
\hline LEVEL 1 & -39.68035 & -39.69944 & -39.68117 & -39.68109 & -39.69493 & -39.69086 & -39.68833 \\
\hline LEVEL 2 & -39.68153 & -39.69549 & -39.69399 & -39.70264 & -39.69301 & -39.69392 & -39.68647 \\
\hline LEVEL 3 & -39.70691 & -39.67386 & -39.69363 & -39.68506 & -39.68085 & -39.68401 & -39.69400 \\
\hline DELTA & 0.026556 & 0.025571 & 0.01282 & 0.0215445 & 0.014078 & 0.00991 & 0.00753 \\
\hline RANK & 1 & 2 & 5 & 3 & 4 & 6 & 7 \\
\hline
\end{tabular}

\section{Analysis of Result}

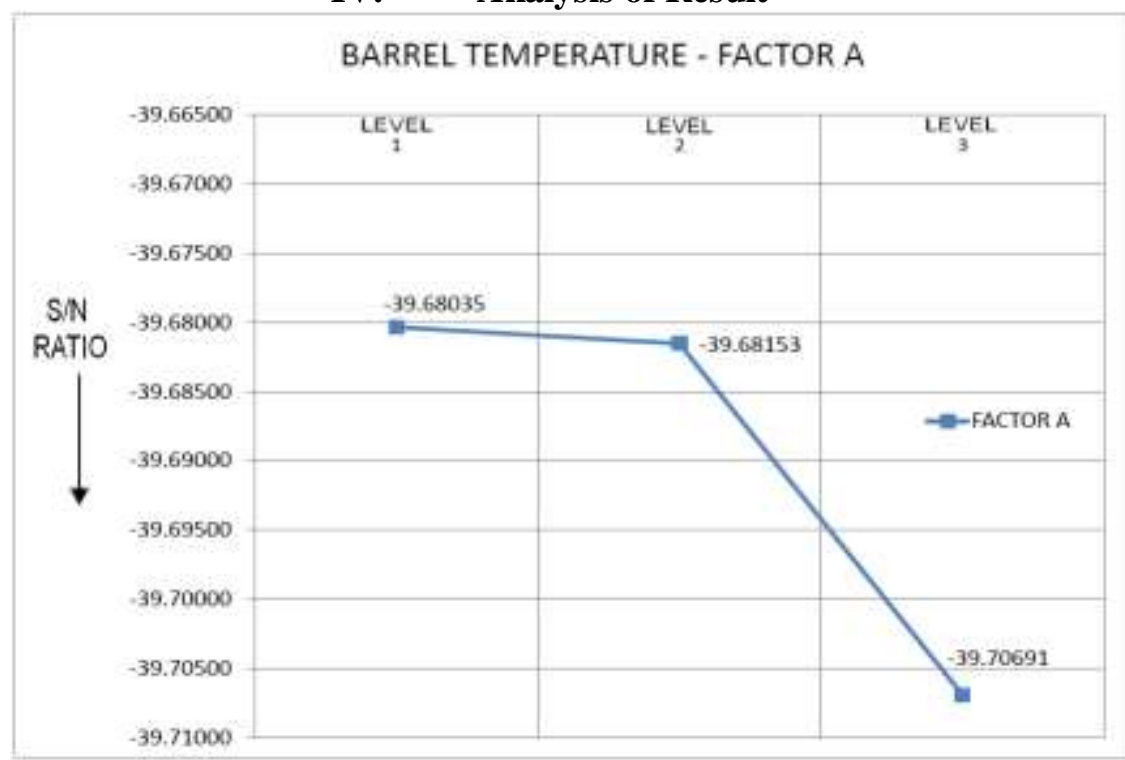

Figure No. 2 S/N Ratio Curve for Barrel Temperature

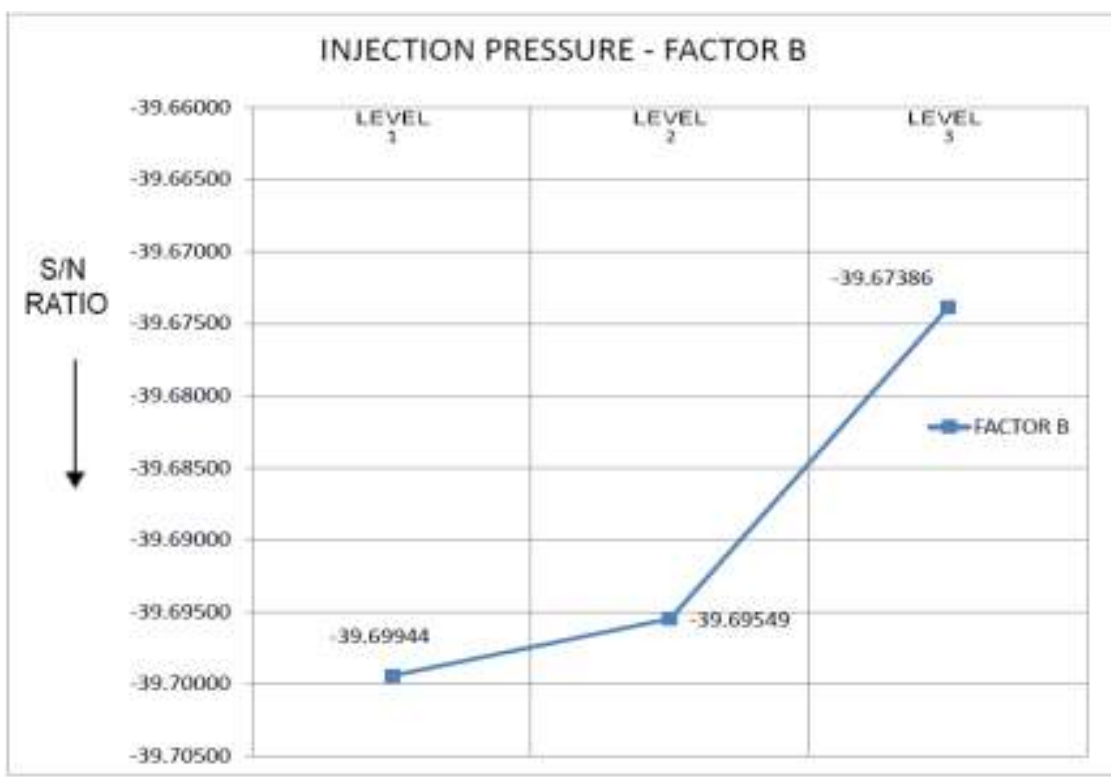


Figure No. 3 S/N Ratio Curve for Injection Pressure

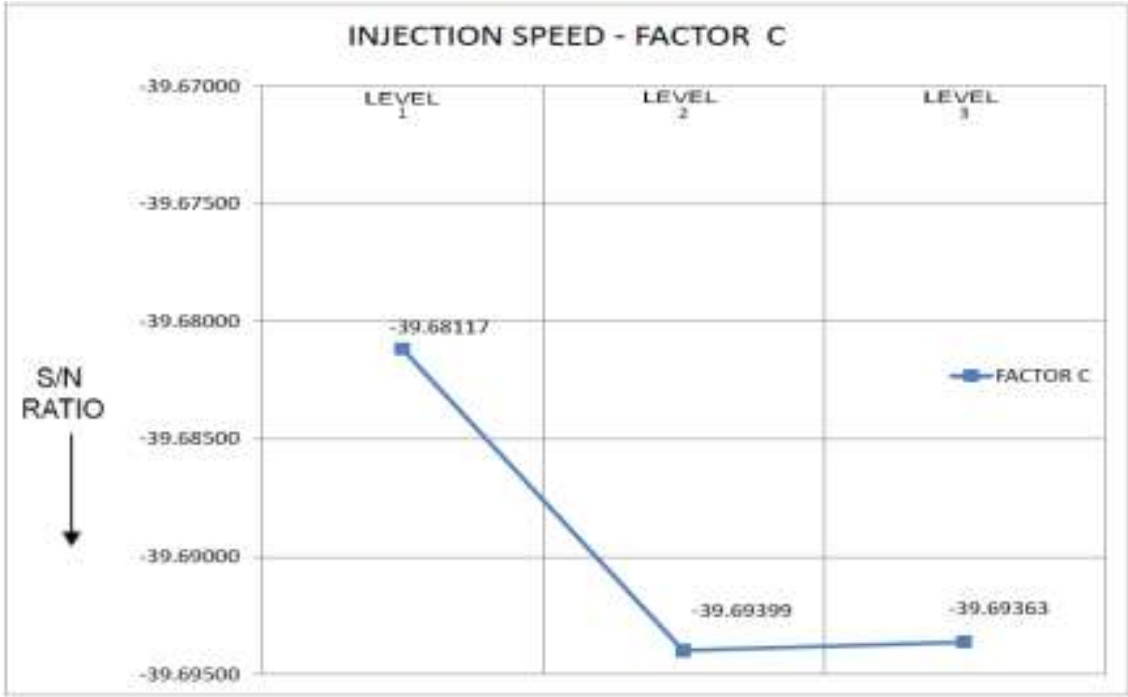

Figure No. 4 S/N Ratio Curve for Injection Speed

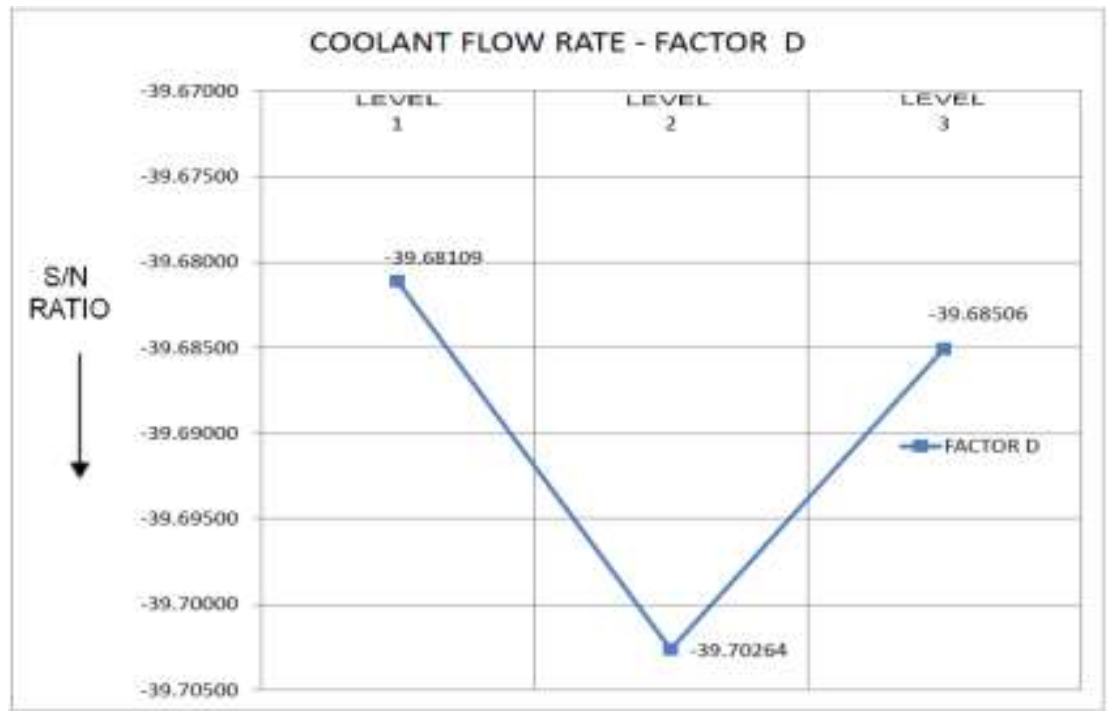

Figure No. 5 S/N Ratio Curve for Coolant Flow Rate

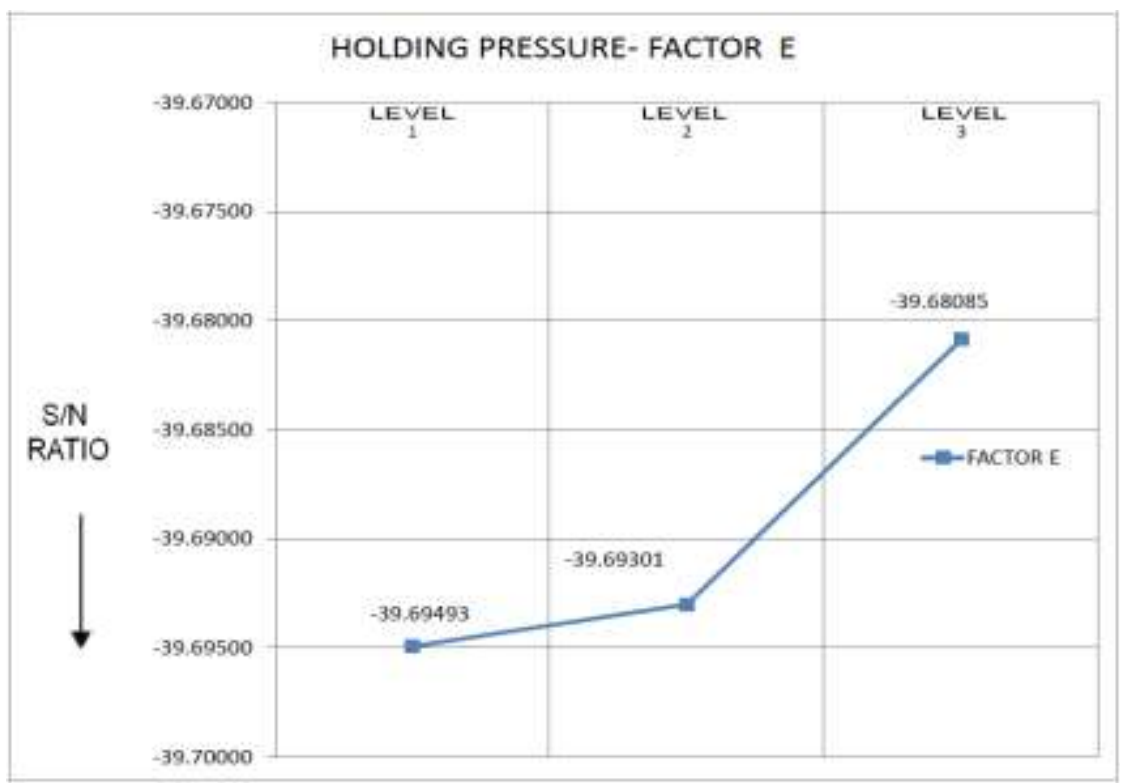


Figure No. 6 S/N Ratio Curve for Holding Pressure

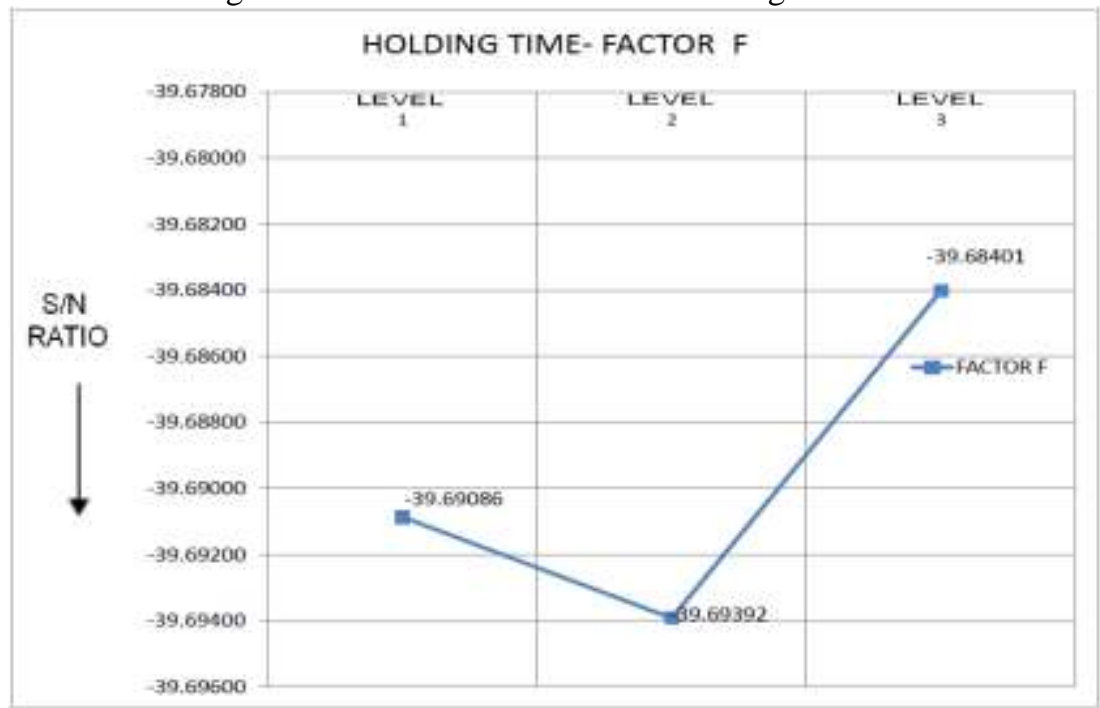

Figure No. 7 S/N Ratio Curve for Holding Time

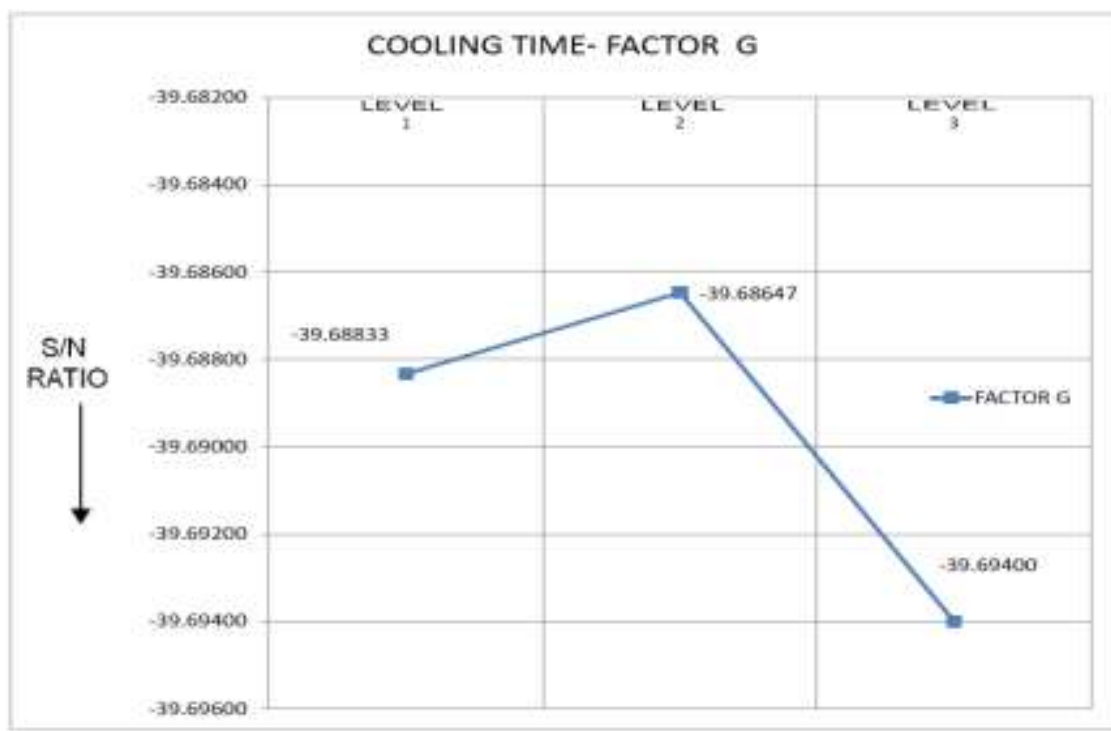

Figure No. 8 S/N Ratio Curve for Cooling Time

1) The Barrel Temperature contributes the maximum $31.93 \%$ to the output response Weight and is most significant at Level 3 which corresponds to $235^{\circ} \mathrm{C}$ and F- ratio of 50.792 at 99\% Confidence Interval (Fig. 2)

2) The Injection Pressure contributes the second highest $26.81 \%$ to the output response Weight and is most significant at Level 1 which corresponds to $30 \mathrm{MPa}$ and F-ratio of 42.65 at 99\% Confidence Interval (Fig. 3)The Injection speed contributes $7.55 \%$ to the output response Weight and is most significant at Level 2 which corresponds to $45 \%$ and F-ratio of 12.01 at 95\% Confidence Interval. (Fig. 4)The Coolant Flow Rate contributes $18.64 \%$ to the output response Weight and is most significant at Level 2 which corresponds to 7 LPM and F-ratio of 29.66 at $95 \%$ Confidence Interval. (Fig. 5)

3) The Holding Pressure contributes $8.25 \%$ to the output response Weight and is most significant at Level 1 which corresponds to $35 \mathrm{MPa}$ and F-ratio of 13.13 at 95\% Confidence Interval. (Fig. 6)

4) The Holding Time contributes $3.66 \%$ to the output response Weight and is most significant at Level 2 which corresponds to 1.75 second and F-ratio of 5.843 at 90\% Confidence Interval. (Fig. 7)

5) The Cooling Time was considered insignificant due to lower F-ratio and hence was pooled with experimental error value. The pooled error $\left(\mathrm{E}_{\mathrm{p}}\right)$ contributes $3.1266 \%$ to the output response Weight. (Fig. 8)

\section{Experimental Verification}

After performing the statistical analysis on the experimental data, it has been observed that there is one particular level for each factor for which the responses are minimum. Considering these levels as optimal levels a verification experiment is designed and process reliability is verified along with the capability estimate [11]. 
Table No. 9 Optimal Parameter Settings of Input Factors

\begin{tabular}{|l|c|c|c|c|c|c|}
\hline & \multicolumn{6}{|c|}{ Parameters } \\
\cline { 2 - 7 } & $\mathrm{A}$ & $\mathrm{B}$ & $\mathrm{C}$ & $\mathrm{D}$ & $\mathrm{E}$ & $\mathrm{F}$ \\
\hline $\begin{array}{l}\text { Factor } \\
\text { Levels }\end{array}$ & 235 & 30 & 45 & 7 & 35 & 2.0 \\
\hline
\end{tabular}

$\mu_{\text {est }}=$ estimated Mean

$$
\begin{aligned}
& \mathrm{CI}=\sqrt{F_{\alpha ; 1 ; \nu_{e}} \cdot \mathrm{V}_{\mathrm{ep}} \cdot\left[\left(1 / \mathrm{n}_{\text {eff }}\right)+(1 / r)\right]} \\
& \mathrm{n}_{\mathrm{eff}}=\frac{\mathrm{N}}{1+\text { DOF used in } \boldsymbol{u} \text { estimate }}
\end{aligned}
$$

$\mathrm{r}=$ sample size used for verification $=5$

$\mu_{\mathrm{est}}=\mu_{\mathrm{A} 3 \mathrm{~B} 1 \mathrm{C} 3 \mathrm{D} 3 \mathrm{E} 1 \mathrm{~F} 3}=$ the estimate of average weight at the optimum levels of each factors

$$
=\left[\sum \mathrm{A} 3 / 6+\sum \mathrm{B} 1 / 6+\sum \mathrm{C} 2 / 6+\sum \mathrm{D} 2 / 6+\sum \mathrm{E} 1 / 6+\sum \mathrm{F} 3 / 6\right]-5 \times \mathrm{T}_{\mathrm{m}}
$$

$\mu_{\mathrm{est}}=\mu_{\mathrm{A} 3 \mathrm{~B} 1 \mathrm{C} 3 \mathrm{D} 3 \mathrm{E} 1 \mathrm{~F} 3}=96.82578$ gram

$\mathrm{F}_{0.01 ; 1 ; 5 ;}=16.8 ; \quad----\mathrm{F}$ Value at $99 \%$ Confidence Interval

$\mathrm{V}_{\mathrm{ep}}=0.00653 ;$---- Value of pooled error from TABLE No. 7

$\mathrm{r}=5$;

$\mathrm{n}_{\mathrm{eff}}=[1+($ Degrees of Freedom of six factors in verification $)]$

$\mathrm{n}_{\mathrm{eff}}=\mathrm{N} /[1+(2+2+2+2+2+2)]$

$\mathrm{n}_{\mathrm{eff}}=18 / 13=1.3846$

$C I=\sqrt{ }\left[F_{0.01 ; 1 ; 5 ;}, \overline{\left.V_{e p}\left[\left(1 / n_{\text {eff }}\right)+(1 / r)\right]\right]}\right.$

$\mathrm{CI}=\sqrt{ }[16.8 * 0 . \overline{00653 *[(1 / 1.3846)+(1 / 5)]]}$

$\mathrm{CI}=0.3181=0.318$

$\mu_{\text {est }} \pm \mathrm{CI}=\mu_{\mathrm{A} 3 \mathrm{~B} 1 \mathrm{C} 3 \mathrm{D} 2 \mathrm{E} 1 \mathrm{~F} 2} \pm \mathrm{CI}$

$\mu_{\mathrm{est}}-\mathrm{CI}<\mu<\mu_{\mathrm{est}}+\mathrm{CI}$

$96.922-0.318<\mu<96.922+0.318$

$96.5077<\mu<97.1437$

Since the value of $\mu_{\text {est }}$ falls within the above range, the parameter settings and design is reliable.

The USL for given part is 98 grams.

The LSL for given part is 96.04 grams with $2 \%$ tolerance on USL

$\mathrm{S}_{\mathrm{e}}=$ Pooled Error Standard Deviation $=\left(\mathrm{V}_{\mathrm{ep}}\right)^{1 / 2}$

$\mathrm{S}_{\mathrm{e}}=0.0808$

\subsection{Capability Estimates (6s process variation)}

Typically, process variation is defined as $6 \mathrm{~s}$, where $\mathrm{s}$ is the standard deviation, as an estimate of $\sigma$. When data are normally distributed, approximately $99.73 \%$ of the data fall within 6 standard deviations $( \pm 3$ standard deviations from the mean), and approximately $99 \%$ of the data fall within5.15 standard deviations ( \pm 2.575 standard deviations from the mean).

Therefore process capability $\mathrm{C}_{\mathrm{p}}=(\mathrm{USL}-\mathrm{LSL}) /\left(6 \mathrm{~S}_{\mathrm{e}}\right)$

$$
\mathrm{C}_{\mathrm{p}}=4.042
$$

$\mathrm{C}_{\mathrm{pu}}=\left(\mathrm{USL}-\mu_{\mathrm{est}}\right) /\left(3 \mathrm{~S}_{\mathrm{e}}\right)=4.8444$

$\mathrm{C}_{\mathrm{pl}}=\left(\mu_{\mathrm{est}}-\mathrm{LSL}\right) /\left(3 \mathrm{~S}_{\mathrm{e}}\right)=3.241$

Minimum of $\mathrm{C}_{\mathrm{pu}}$ and $\mathrm{C}_{\mathrm{pl}}$ is compared with $\mathrm{C}_{\mathrm{p}}$ and since, $\mathrm{C}_{\mathrm{pl}}<\mathrm{C}_{\mathrm{p}}$ it means the process is off-centered. 


\subsection{Verification Result}

The verification experiment was conducted and the cooling time was maintained at 6 sec with all other parameters at their optimal levels from TABLE No. 9.

The part weight measured at this setting was 96.539 grams with a cycle time of 28.1 second.

The optimal setting results in a part weight which falls within the process limits defined by the Confidence Level Equation used to verify predictions. Hence the values obtained from the Capability Estimates and the output of the Confirmation Experiment prove that the defined levels of parameters have significant contribution in making the system reliable. it has been observed that the part weight is within the acceptable range. So it can be concluded that the combinations of parameters tend to reach towards optimum settings.

Table No. 10 Verified Optimal Parameter Levels of Input Factors

\begin{tabular}{|c|c|c|c|c|c|c|}
\hline & \multicolumn{7}{|c|}{ Parameters Values } \\
\cline { 2 - 7 } & $\mathrm{A}$ & $\mathrm{B}$ & $\mathrm{C}$ & $\mathrm{D}$ & $\mathrm{E}$ & $\mathrm{F}$ \\
\hline Pre Experimental Values & 230 & 35 & 40 & 11 & 30 & 2.5 \\
\hline $\begin{array}{c}\text { Optimal Parameter values } \\
\text { for Min.Weight }\end{array}$ & 235 & 30 & 45 & 7 & 35 & 1.75 \\
\hline
\end{tabular}

\subsection{Highlights of the Experiment}

1) Cycle Time was reduced by 4 second as against the cycle time prior to experimentation recorded was 32.4 second. The percent saving in production was $12.5 \%$, we can reasonably comment that productivity was enhanced by $12.5 \%$.

2) The reduced injection pressure lessens the clamping force required and in turns results in reduced power consumption per part weight due to reduction in power required for clamping.

3) Reduced part weight contributes to material savings.

\section{Conclusion}

1) In search of an optimal parameter combination, (favorable process environment) capable of producing desired quality of the product in a relatively lesser time (enhancement in productivity), the Taguchi methodology has been characteristically successful.

2) The study proposes a consolidated optimization approach using Taguchi's robust design of optimization .The Methodology could serve in minimizing the cost to customer by enhancing quality and production aspects.

3) In Taguchi $\mathrm{L}_{18}$ orthogonal matrix experiment, no interactions between the input factors are considered. But some interaction effect may be present during the experiment. This may result in some observations which do not go with the theoretical belief though not observed during the course of experimentation.

4) Since the material is a polymer of specific grade, parallels cannot be drawn in results with analogical experimentations. But, the experimental method can be analogically applied to most of the polymers with some minor deviations.

\section{References}

[1] M. Huang, and T. Lin, Simulation of a regression-model and PCA based searching method developed for setting the robust injection molding parameters of multi-quality characteristics, International Journal of Heat and Mass Transfer, 2008, (Online Copy).

[2] Y. Gao, and X. Wang, Surrogate-based process optimization for reducing warpage in injection molding, Journal of Materials Processing Technology, 2008, (Online Copy).

[3] S. Changyu, W. Lixia, and L. Qian, Optimization of injection molding process parameters using combination of artificial neural network and genetic algorithm method, Journal of Materials Processing Technology, 183, 2007, 412-418.

[4] J. Zhu, J. Chen, and E. Kirby, Tensile Strength and Optimization of Injection Molding Processing Parameters Using the Taguchi Method", The International Journal of Modern Engineering, 4(2), Spring 2004

[5] K. Alam, and M. Kamal, A robust optimization of injection molding runner balancing, Computers and Chemical Engineering, 29, 2005, 1934-1944.

[6] S. Tang, Y. Tan, S. Sapuan, S. Sulaiman, N. Ismail, and R. Samin, The use of Taguchi method in the design of plastic injection mold for reducing warpage, Journal of Materials Processing Technology, 182, 2007, 418-426.

[7] H. Zhou, B. Yan, and Y. Zhang, 3D filling simulation of injection molding based on the PG method, Journal of Materials Processing Technology, 204, 2008, 475-480.

[8] Y. Shen, C. Wu, Y. Yu, and H. Chung, Analysis for optimal gate design of thin-walled injection molding, International Communications in Heat and Mass Transfer, 35, 2008, 728-734.

[9] T. Zhil'tsova, M. Oliveira, and J. Ferreira, Relative influence of injection molding processing conditions on HDPE acetabular cups dimensional stability, Journal of Materials Processing Technology, 2008, (Online Copy).

[10] D. V. Rosato, N. R. Schott, and M. G. Rosato, Plastics Engineering, Manufacturing \& Data Handbook, (Boston: Springer, 2001) 406-407.

[11] P. J. Ross, Confirmation Experiment, Taguchi Techniques for Quality Engineering, 6 (New Delhi: Tata Mc-Graw Hill, 2005) 181201. 